\title{
Fe-Ti-Y (Iron-Titanium-Yttrium)
}

V. Raghavan

[1994Zen] determined an isothermal section for this system at $500{ }^{\circ} \mathrm{C}$. With starting metals of purity $99.9 \% \mathrm{Fe}$, $99.8 \% \mathrm{Ti}$, and $99.9 \% \mathrm{Y}$, [1994Zen] prepared 102 alloy compositions by induction melting under Ar atm. The alloys were homogenized at $900{ }^{\circ} \mathrm{C}$ for 30 days and finally annealed at $500{ }^{\circ} \mathrm{C}$ for 5 days and quenched in an ice-water mixture. The phase equilibria were studied mainly by $\mathrm{x}$-ray powder diffraction. Supplemental results were obtained by using scanning electron microscopy with energy-dispersive x-ray analysis and differential thermal analysis. The isothermal section of [1994Zen] at $500{ }^{\circ} \mathrm{C}$ (not reproduced here) has the same phase distribution as that at $600{ }^{\circ} \mathrm{C}$ obtained by [1997Liu] using ternary diffusion couples (reviewed by [2000Rag]). One ternary compound $\mathrm{YFe}_{11} \mathrm{Ti}$ with the
$\mathrm{ThMn}_{12}$-type tetragonal structure is present at both 500 and $600{ }^{\circ} \mathrm{C}$ and the triangulations are identical. [1994Zen] reported a small solubility of $\mathrm{Ti}$ of 1.5 at.\% in $\mathrm{Fe}_{17} \mathrm{Y}_{2}$, not observed by [1997Liu]. The lattice parameters of $\mathrm{YFe}_{11} \mathrm{Ti}$ determined by [1994Zen] are $a=0.8514 \mathrm{~nm}$ and $c=$ $0.4798 \mathrm{~nm}$.

\section{References}

1994Zen: L. Zeng, J. Li, X. Sun, and Y. Zhuang: Z. Metallkd., 1994, vol. 85 (9), pp. 625-27.

1997Liu: Z. Liu, Z. Jin, and C. Xia: Scripta Mater., 1997, vol. 37 (8), pp. 1129-34.

2000Rag: V. Raghavan: J. Phase Equilibria, 2000, vol. 21 (5), p. 467. 